\title{
Cytotoxicity and genotoxicity of fenoxaprop-p-ethyl and fluzifob-p-butyl herbicides
}

\author{
Bahar Ulus, Müzeyyen Çeliksöz*, Gül Özhan \\ Department of Pharmaceutical Toxicology, Faculty of Pharmacy, İstanbul University, 34116 İstanbul, Turkey
}

Cite this article as: Ulus B, Celiksöz M, Özhan G (2017). Cytotoxicity and genotoxicity of fenoxaprop-p-ethyl and fluzifob-pbutyl herbicides. Istanbul J Pharm 47 (1): 5-8

\begin{abstract}
Human populations are exposed to several toxic substances in the environment, including pesticides. Fenoxaprop-p-ethyl (FPE) and fluzifob-p-butyl (FPB) herbicides are extensively used in agricultural fields due to their high target selectivity and low non-target toxicity. They are known as aryloxyphenoxypropionate herbicides, and acetyl-CoA carboxylase inhibitor. In the study, we aimed to evaluate the toxic potentials of FPE and FPB herbicides. Cell viability was evaluated by MTT assay in the range of 15.6-500.0 $\mu \mathrm{M}$ exposure concentrations in mouse fibroblast (BALB/3T3) cell line. Also, we investigated their DNA damage potentials on BALB/3T3 cells by using alkaline Comet assay. The results indicated that FPE and FPB showed no evidence of DNA damage. And, the cell viability was more than $20 \%$ at $12.5-400 \mu \mathrm{M}$ exposure concentrations. FPE and FPB might be safe according to our results and the previously studies, and there would be public health benefits from encouraging its use in the place of more toxic herbicide products.
\end{abstract}

Keywords: Fenoxaprop-p-ethyl, fluzifob-p-butyl, $3 T 3$ cells

\section{INTRODUCTION}

Exposure to herbicides have become compulsory with increasing world population, is a global problem due to their toxic potentials although increasing the yield and quality of agricultural products. Herbicides are used for controlling several pests and weeds, even if they remain as residues in food, air, and water. There is a great deal of information that herbicides and their residues have negative effects on human and environmental health (Abd-Alrahman et al. 2014; Morrison et al. 1992; Saunders and Harper 1994). Herbicides The chemicals could affect human populations by direct exposure during production or application, or indirect exposure by oral ingestion of residues in cereals, vegetables and fruits or animal products (Betancourt and Reséndiz 2006).

FBE and FPB, members of aryloxy phenoxy propanoate herbicides, inhibit growth and lipid biosynthesis in grass species (Bakkali et al. 2007). The effect is related to the inhibition of acetyl-CoA carboxylase, a key enzyme in long-chain fatty acid biosynthesis (Shimabukuro and Hoffer 1995). FPE and FPB are mostly used as post-emergence to control grasses, although herbicides are attracting public attention (Hay 1981; Hongming et al. 2015; Yasin et al. 2013). FPE is a more recently formulated herbicide for weed control in wheat, rice, and broad-leafed crops due to its high target selectivity and low non-target toxicity (Bieringer et al. 1982; Tehranchian et al. 2016; Walia et al. 1998). Similarly, FPB is used to kill annual and perennial grasses, and does little or no harm to broad-leaved plants (Olszyk et al. 2013).

FPE inhibits the biosynthesis of fatty acids by affecting acetyl coenzyme A carboxylase.

FPE is found in plant chloroplasts and mammalian liver, and has produced reversible hepatic toxicity (Lin et al. 2007). FPE is rapidly absorbed after oral ingestion and metabolized to benzoxazol mercapturic acid and hydroxyphenoxy propionic acid (Zawahir et al. 2009). FPE is not considered carcinogenic or mutagenic and there are no reports indicating that it could be harmful to human 
fertility or reproduction (Casas et al. 2010; Peterson et al. 2011). However, Asshauer et al. (1990) indicate that FPE is harmful to aquatic organism.

FPB catalyzes the formation of malonyl-CoA during metabolism of lipids and/or of some secondary compounds (Horbowicz et al. 2013). FPB is of relatively low toxicity to birds and mammals, however, FPB is can be an irritant (eye, skin, respiratory passages, and skin sensitizer), and is toxic when to be inhaled. There are limited data about its toxicity. Tu et al. (2001) indicated FPB could be highly toxic to fish and aquatic invertebrates in aquatic systems. Also, it is thought that the weight loss in animals might be associated with reduction of the acetyl coenzyme carboxylase enzyme caused by FPB and its metabolites in mammalian studies (Ore and Olayinka 2016; Tong 2005).

In the present study, the toxic potential of FPE and FPB were investigated using MTT- cytotoxicity and Comet-genotoxicity assays because there are no reports indicating their cytotoxic and genotoxic effects on mouse fibroblast BALB/3T3 cell line.

\section{MATERIALS AND METHODS}

\section{Chemicals}

Cell culture medium (Dulbecco's Modified Eagle's Medium, DMEM), fetal bovine serum (FBS), phosphate buffered saline (PBS, 10X) and antibiotic solutions were purchased from Multi cell Wisent (Quebec, Canada). The herbicides standards, FPE and FPB were obtained from Riedel-de Haen (Seelze, Germany). MTT (3-[4,5-dimethylthiazol-2-yl]-2,5-diphenyl-tetrazolium bromide) was obtained from Sigma Chemical Co. Ltd. (St. Louis, MO, USA). All other chemicals were obtained from Merck (NJ, USA). Stock standard solutions of $100 \mu \mathrm{M}$ of FPE and FPB were prepared in DMSO.

\section{Cell culture conditions}

Mouse embryo fibroblast cell line BALB/3T3 (American Type Culture Collection ATCC ${ }^{\circledR}$ CRL $163^{\mathrm{TM}}$, Rockville, MD, USA) was used. The cell was cultured in DMEM supplemented with 10\% $(\mathrm{v} / \mathrm{v})$ FBS, $2 \mathrm{mM}$ L-glutamine, 100 units $/ \mathrm{mL}$ of penicillin, 100 $\mathrm{\mu g} / \mathrm{mL}$ of streptomycin at $5 \% \mathrm{CO}_{2}, 90 \%$ humidity, and $37^{\circ} \mathrm{C}$ for $24 \mathrm{~h}$ (70-80\% confluence). The cell densities for each tests were in the range from $1 \times 0^{4}$ to $1 \times 10^{7}$ cells $/ \mathrm{mL}$ for all assays (Abudayyak et al. 2017).

\section{Cytotoxicity assay}

Cytotoxic activities of FPE and FPB were determined by MTT (mitochondrial succinate dehydrogenase) assay. The cells were seeded in 96-well plates at a density of $1 \times 10^{4}$ cells/well, and treated for $24 \mathrm{~h}$ with FPE and FPB in the concentration range of 15.6, 31.2, 62.6, 125, 250 and $500 \mu \mathrm{M}$. MTT is a water-soluble, yellow-colored salt reduced by the mitochondrial succinate dehydrogenase to insoluble purple formazan product. Mitochondrial succinate dehydrogenase is only active in viable cells. Therefore, in the MTT assay, color changes by activity of the enzyme are used as a cytotoxicity endpoint (Van Meerloo et al. 2011). Optical density (OD) values were read at $590 \mathrm{~nm}$ using a microplate spectrophotometer system (Epoch, Germany). In every assay, unexposed cells served as a negative control. DMSO was added to the negative control cells at a final concentration of $1 \%(\mathrm{v} / \mathrm{v})$, which was related to the maximal concentration of the solvent compounds used in the experiment. The inhibition of enzyme activity observed in cells was calculated and compared to a negative control. The inhibitory concentration (IC) was then expressed as the concentration of sample causing percentage of inhibition of enzyme activity in cells.

\section{Genotoxicity assay}

Genotoxic activities of FPE and FPB were determined by Comet assay. The cells were seeded in 6-well plates at $2.5 \times 10^{5}$ cells/ well. After that, the cells were treated with FPE and FPB at 25 , $50,100,200$ and $400 \mu \mathrm{M}$ concentrations in 1\% DMSO during $24 \mathrm{~h}$. The cells were washed with PBS, trypsinized, centrifuged at $250 \mathrm{~g}$ for $3 \mathrm{~min}$ and re-suspended into $1 \mathrm{~mL}$ fresh medium. $1 \%$ DMSO and $100 \mu \mathrm{M}$ of hydrogen peroxide $\left(\mathrm{H}_{2} \mathrm{O}_{2}\right)$ were used as solvent and positive controls. For positive control, the cells were incubated with $\mathrm{H}_{2} \mathrm{O}_{2}$ for 30 min.

The viability of cells was checked with trypan blue dye exclusion; cells viability was $80 \%$ in all concentrations. Briefly, $80 \mathrm{~mL}$ of cells was mixed with $180 \mathrm{~mL}$ of pre-warmed low-melting point agarose ( $0.65 \%$ in PBS), layered on conventional microscope slides pre-coated with normal-melting point agarose (1.5\% in distilled water) and covered with cover slip. After solidification at $4^{\circ} \mathrm{C}$, the cover slips were removed and slides were incubated for $1 \mathrm{~h}$ at $4^{\circ} \mathrm{C}$ in lysis solution $(2.5$ $\mathrm{M} \mathrm{NaCl}, 100 \mathrm{mM}$ EDTA, and $10 \mathrm{mM}$ tris- $\mathrm{HCl}, \mathrm{pH}$ 10), extemporarily added with $10 \%$ DMSO and $1 \%$ triton X-100. DNA was unwinded for 20 min in cold-fresh electrophoresis buffer $(0.3 \mathrm{M} \mathrm{NaOH}, 1 \mathrm{mM}$ EDTA, $\mathrm{pH}$ 13) at $4^{\circ} \mathrm{C}$ and electrophoresis was performed at $4^{\circ} \mathrm{C}$ for $20 \mathrm{~min}$ (20 V/300 mA) (Speit and Hartmann 1999). Then, the slides were neutralized with $0.4 \mathrm{M}$ tris-HCl buffer ( $\mathrm{pH}$ 7.5) 3 times for $5 \mathrm{~min}$, and were fixed in absolute ethanol. DNA was stained with ethidium bromide (20 mg/mL) just before slide examination under a fluorescent microscope (Olympus, Japan) at 400 magnification by using an automated image analysis system (Comet Assay IV, Perceptive Instruments, UK). A total of 100 cells were scored per concentration and DNA damage to individual cells was expressed as a percentage of DNA in the Comet tail (\% $\mathrm{T}_{\mathrm{DNA}^{\prime}}$ tail intensity). Every step was performed under indirect light. Protocol was performed in triplicate to ensure reproducibility.

\section{Statistical analysis}

All experiments were done in triplicate and each assay was repeated twice. Data was expressed as mean \pm standard deviation (SD). The significance of differences between unexposed and exposed cells with the herbicides was calculated by one-way ANOVA Dunnett t-test using SPSS version 17.0 for Windows (SPSS Inc., Chicago, IL, USA). P values of less than 0.05 were selected as the levels of significance.

\section{RESULTS AND DISCUSSION}

In the present study, the effects of FPE and FPB on cell viability and DNA damage biomarkers in vitro conditions has been investigated because there are no reports related to their cytotoxic and genotoxic potentials. As it is well known, many commercial herbicide formulations are highly toxic; whereas the case fatality for the herbicide product containing FPE is relatively low (Dorn et al. 2009). Two groups claimed that FPE was not considered carcinogenic or mutagenic, or harmful to human fertility or reproduction (Casas et al. 2010; Peterson et al. 2011). Lin et al. (2007) indicated FPB was hepatotoxic in long-term study for 

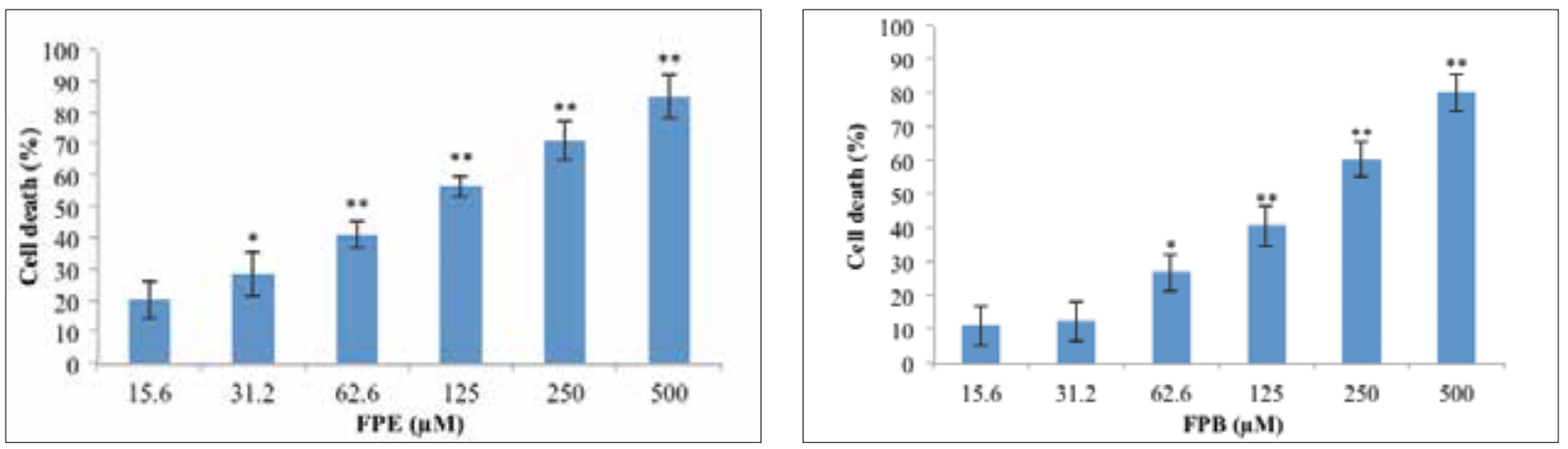

Figure 1. a, b. Effects of FPE (a) and FPB (b) on cell viability by MTT.

Values are expressed as mean $\pm \mathrm{SD} ; \mathrm{n}=6$ for each treatment group.

*Significantly different from DMSO control group ( $p<0.05$ ).

**Significantly different from DMSO control group $(p<0.001)$

\section{Table 1. Evaluation of genotoxic potentials of FPE and FPB by Comet assay.}

\begin{tabular}{|lcc|}
\hline & \multicolumn{2}{c|}{ Mean tail intensity $\left(\% \mathrm{~T}_{\text {DNA }}\right) \pm \mathrm{SE}$} \\
\cline { 2 - 3 } & $\mathrm{FPB}$ & $\mathrm{FPE}$ \\
& $(\mu \mathrm{M})$ & $0.54 \pm 0.10$ \\
\hline $\mathrm{PBS}$ Control & $0.54 \pm 0.10$ & $56.09 \pm 0.02$ \\
$\mathrm{H}_{2} \mathrm{O}_{2}(100 \mu \mathrm{M})$ & $56.09 \pm 0.84$ & $0.70 \pm 0.22$ \\
12.5 & $1.12 \pm 0.09$ & $1.92 \pm 0.58$ \\
25 & $0.41 \pm 0.00$ & $1.96 \pm 0.55$ \\
50 & $0.80 \pm 0.38$ & $2.64 \pm 0.96$ \\
100 & $1.93 \pm 0.41$ & $1.62 \pm 0.72$ \\
200 & $1.60 \pm 0.68$ & $3.43 \pm 0.72$ \\
400 & $1.70 \pm 0.48$ & \multicolumn{3}{l}{} \\
\hline All experiments were done in triplicates and each assay as repeated twice. \\
The results were presented as mean tail intensity $(\%)$. NC mean negative \\
controls, respectively.
\end{tabular}

mice. Kopec and Lembowicz (2002) observed the effect of herbicide $\mathrm{FPB}$, on the early occurring changes in rat liver regarded as hepatic markers of peroxisome proliferators. Similarly, Kostka et al. (2002) indicated short term treatment of rats with FPB resulted in hepatomegaly due to time dependent proliferation of smooth endoplasmic reticulum and peroxisomes at $56 \mathrm{mg} / \mathrm{kg}$ body weight per day.

According to our results, all herbicides reduced the cell viability in a concentration-dependent manner. The cell viability at $37.12,62.5,125$, and 250 and $500 \mu \mathrm{M}$ concentrations of FPE and FPB on fibroblast cells were showed in Figure 1. IC $\mathrm{C}_{50}$ ( $50 \%$ inhibition of enzyme activity) values of FPE and FPB were 392.88 and $231.37 \mathrm{mM}$, respectively.

Karadeniz et al. (2015) tested the viability and proliferation effects of FPE and FPB on human immortalized embryonic kidney HEK293 cells which examined with MTT and trypan-blue exclusion assays. They reported that herbicides did not affected the proliferation rate of the HEK293 cells but both induced cell death at high concentrations, as determined in our study.

According to data from Extoxnet (1996), FPB has shown very high to high toxicity in bluegill sunfish ( $\left(\mathrm{LC}_{50}=2.28 \mu \mathrm{M}\right.$ for $\left.96 \mathrm{~h}\right)$ and rainbow trout $\left(\mathrm{LC}_{50}=5.9 \mu \mathrm{M}\right.$ for $\left.96 \mathrm{~h}\right)$. Betancourt and Reséndiz (2006) observed with a computer-assisted semen analyzer that FPE was affected the sperm viability by being mediated at the level of the mitochondrion.

According to our Comet assay results, the genotoxic potentials of FPE and FPB were showed in Table 1. Based on our cytotoxicity results, the range of 12.5-400 $\mu \mathrm{M}$ concentration was selected as the exposure concentration for Comet assay in fibroblast cells. So, the cell viability was observed more than $40 \%$ compared to negative control in this concentration range. In positive controls (100 $\mu \mathrm{M} \mathrm{H}_{2} \mathrm{O}_{2}$ ), the tail intensity ranged from $55.25-56.96 \%$. The results revealed that FPE and FPB did not induce DNA damage. At the highest concentration of FPE $(400 \mu \mathrm{M})$, tail intensities were 1.70\%, which are approximately $\leq 1.631$-fold of the negative control. Ore and Olayinka (2016) observed that FPB impaired renal and hepatic functions, and induced oxidative stress induced in treatment groups received FPB at $18.75-75 \mathrm{mg} / \mathrm{kg}$ body weight per day for 21 days by rat study. Also, they reported that FPB induced oxidative stress-mediated alteration of testicular functions in rat. We showed that FPE and FPB did not induce DNA damage. However, Ore et al. reported FPB is capable of causing testicular oxidative stress in vivo. Similarly, Karadeniz et al. (2015) showed that FPB and FPE possessed mutagenic and recombinogenic effects by using the somatic mutation and recombination test (SMART) in Drosophila wings. For the SMART assay, two different crosses were used: a standard (ST) and a high bioactivation (HB) cross. And, they observed that FPB and FPE did not increase the spot frequency in both ST and HB crosses.

All experiments were done in triplicates and each assay as repeated twice. The results were presented as mean tail intensity (\%). NC mean negative controls, respectively.

In conclusion; we observed that FPE and FPB did not induce DNA damage. The findings should be supported with in vivo studies are needed to fully understand their toxicity mechanism. However, it shouldn't be ignored that FPE and FPB might be safe, and there would be public health benefits from encouraging its use in the place of more toxic herbicide products.

\section{Acknowledgements}

This work was funded by the Research Fund of Istanbul University (Project number: 23676). The authors declare that there are no conflicts of interest. 


\section{REFERENCES}

- Abd-Alrahman SH, Elhalwagy ME, Kotb GA, Farid H, Farag AA, Draz HM, Isa AM, Sabico S (2014). Exposure to difenoconazole, diclofop-methyl alone and combination alters oxidative stress and biochemical parameters in albino rats. Int J Clin Exp Med 7 (10): 3637.

- $\quad$ Abudayyak M, Altıncekic T, Özhan G (2017). In vitro toxicological assessment of cobalt ferrite nanoparticles in several mammalian cell types. Biol Trace Element Res 175 (2): 458-465. [CrossRef]

- Asshauer J, Dorn E, Fischer R, Kurzmeier E (1990). Behaviour of fenoxaprop-ethyl in the environment-degradation and effect in the ecosystem. Z Pflanzenkr Pflanzenschutz 12: 417-425.

- Bakkali Y, Ruiz-Santaella J P, Osuna M D, Wagner J, Fischer A J, De Prado R (2007). Late watergrass (Echinochloa phyllopogon): mechanisms involved in the resistance to fenoxaprop-p-ethyl. J Agric Food Chem 55 (10): 4052-4058. [CrossRef]

- $\quad$ Betancourt M, Reséndiz A (2006). Effect of two insecticides and two herbicides on the porcine sperm motility patterns using computer-assisted semen analysis (CASA) in vitro. Reprod Toxicol 22 (3): 508-512. [CrossRef]

- $\quad$ Bieringer H, Horlein G, Langeluddeke P, Handte R (1982). HOE 33171: A new selective herbicide for the control of annual and perennial warm climate grass weeds in broadleaf crops, In. Proc Brighton Crop Prot Conf-Weeds 1: 11-17.

- Casas E, Bonilla E, Ducolomb Y, Betancourt M (2010). Differential effects of herbicides atrazine and fenoxapropethyl, and insecticides diazinon and malathion, on viability and maturation of porcine oocytes in vitro. Toxicol in Vitro 24 (1): 224-230. [CrossRef]

- Dorn E, Schmidt E, Rutz U, Kellner HM, Leist KH (1985). Metabolism in male and female rats after single and repeated oral administration, respectively of a low and a high dose. Hoechst-Roussel Agri-Vet Company, DPR, Pesticide Registration Library Doc. No. 51910-519031.

- Extoxnet (1996). Fluazifop-p-butyl. Pesticide information profiles. Extension Toxicology Network. http://ace.orst. edu/info/extoxnet/

- Hay A (1981). Herbicide safety: Bill of health. Nature 289: 4-5. [CrossRef]

- Hongming L, Xu L, Zhaojian G, Fan Y, Dingbin C, Jianchun Z, Jianhong X, Shunpeng L, Qing H (2015). Isolation of an aryloxyphenoxy propanoate (AOPP) herbicide-degrading strain Rhodococcus ruber JPL-2 and the cloning of a novel carboxylesterase gene (feh). Braz J Microbiol 46 (2): 425432. [CrossRef]

- Horbowicz M, Sempruch C, Kosson R, Koczkodaj D, Walas D (2013). Effect of fluazifop-p-butyl treatment on pigments and polyamines level within tissues of nontarget maize plants. Pestic Biochem Physiol 107 (1): 7885. [CrossRef]

- Karadeniz A, Kaya B, Savaş B, Topcuoğlu F (2015). Effects of two herbicides, fluazyfop-p-butyl and fenoxaprop-p-ethyl, on genotoxicity in drosophila smart assay and on proliferation and viability of hek293 cells from the perspective of carcinogenesis. Fresen Environ Bull 24 (6): 2052-2054.
- Kostka G, Palut D, Ludwicki JK, Kopeć-Szlęzak J, Wiadrowska B, Lembowicz K (2002). Hepatocellular peroxisome proliferation and DNA synthesis in Wistar rats treated with herbicide fluazifop. Toxicol 178 (3): 221-228. [CrossRef]

- $\quad$ Lin J, Chen J, Cai X, Qiao X, Huang L, Wang D, Wang Z (2007). Evolution of toxicity upon hydrolysis of fenoxaprop-p-ethyl. J Agric Food Chem 55 (18): 7626-7629. [CrossRef]

- Morrison HI, Wilkins K, Semenciw R, Mao Y, Wigle D (1992). Herbicides and cancer. J Natl Cancer Inst 84: 1866-1874. [CrossRef]

- $\quad$ Olszyk D, Blakeley-Smith M, Pfleeger T, Lee E H, Plocher M (2013). Effects of low levels of herbicides on prairie species of the Willamette Valley, Oregon. Environ Toxicol Chem 32 (11): 2542-2551. [CrossRef]

- $\quad$ Ore A, Olayinka ET (2016). Fluazifop-p-butyl, an aryloxyphenoxypropionate herbicide, diminishes renal and hepatic functions and triggers testicular oxidative stress in orally exposed rats. Toxicol Ind. Health 0748233716657763. Peterson DE, Regehr DL, Thompson CR, Al-Khatib K, (2011). Herbicide Mode of Action. Kansas State University, Kansas, USA, 9-15.

- Saunders DS, Harper C (1994). Pesticides. In: Hayes AW (ed.), Principles and Methods of Toxicology, 3rd ed. Raven Press, New York, pp. 389-415.

Shimabukuro R H, Hoffer B L (1995). Enantiomers of diclofop-methyl and their role in herbicide mechanism of action. Pestic Biochem Physiol 51 (1): 68-82. [CrossRef]

- $\quad$ Speit G, Hartmann A (1999). The comet assay (Single-Cell Gel Test) a sensitive genotoxicity test for the detection of DNA damage and repair. DNA Repair Protocols: Eukaryotic Systems, 203-212. [CrossRef]

- Tehranchian P, Norsworthy J.K, Korres NE, McElroy S, Chen S, Scott, RC (2016). Resistance to aryloxyphenoxypropionate herbicides in Amazon sprangletop: Confirmation, control, and molecular basis of resistance. Pestic Biochem Physiol 133: 79-84. [CrossRef]

- Tong L (2005). Acetyl-coenzyme a carboxylase: crucial metabolic enzyme and attractive target for drug discovery. Cell Mol Biol 62 (16): 1784-1803. [CrossRef]

- Tu M, Hurd C, Randall JM (2001). Weed control methods handbook: tools \& techniques for use in natural areas. The Nature Conservancy, Report.

- Van Meerloo J, Kaspers GJ, Cloos J (2011). Cell sensitivity assays: the MTT assay. Cancer cell culture: methods and protocols, 237-245. [CrossRef]

- Walia U, Brar L, Dhaliwal B (1998). Performance of clodinafop and fenoxaprop-p-ethyl for the control of phalaris minor in wheat. Ind J Weed Sci 30: 48-50.

- Yasin M, labal Z, Safdar ME, Rehman A, Ali A, Asif M, Aziz M, Tanveer A, Pervez MA (2011). Phalaris minor control, resistance development and strategies for integrated management of resistance to fenoxaprop-ethyl. Afr J Biotechnol 10 (56): 11802-11807.

- Zawahir S, Roberts DM, Palangasinghe C, Mohamed F, Eddleston M, Dawson AH, Buckley NA, Ren L, Medley GA, Gawarammana I (2009). Acute intentional self-poisoning with a herbicide product containing fenoxaprop-P-ethyl, ethoxysulfuron, and isoxadifen ethyl: a prospective observational study. Clin Toxicol 47 (8): 792-797. [CrossRef] 